\title{
Effects of Nitrogen Fertilizer Rate and Inter-Row Spacing on Yield and Yield Components of Teff [Eragrostis teff (Zucc.) Trotter] in Limo District, Southern Ethiopia
}

\author{
Tamirat Wato \\ Lecturer, Department of Plant Sciences, Bonga University. \\ Department of Plant Science, College of Agriculture and Natural Resource, P.O. Box 334, Bonga, Ethiopia
}

\begin{abstract}
Teff [Eragrostis tef (Zucc.) Trotter] is the major staple food of Ethiopia. It ranks the first among cereals in the country in area coverage and second in the production Volume; however, its productivity is almost stagnant. Teff variety Quncho (Dz-Cr-387) was sown during the main cropping season of 2016/2017 at Limo District, Southern Ethiopia. The objective of this research was to study the effect of four nitrogen fertilizer rates $(0,32.5,65$ and $97.5 \mathrm{~kg} \mathrm{~N} / \mathrm{ha}^{-1)}$ and three inter-row spacing $(15,20$ and $25 \mathrm{~cm})$, to evaluate the effects of nitrogen fertilizer rate and inter-row spacing on yield and yield components of teff and to identify the economically appropriate nitrogen rates and inter-row spacing that maximize yield of teff. A factorial experiment was laid out in RCBD with 12 treatment combination and three replications. The characteristics of days to $50 \%$ panicle emergence, days to $90 \%$ physiological maturity, plant height, panicle length, number of effective tillers per plant, lodging index, biological yield, grain yield, thousand seed weight, straw yield, harvest index were measured. The obtained data were subjected to statistical analysis using SAS and means differences were compared using Duncan's Multiple Range Test. The main effects of $\mathrm{N}$ rate and inter-row spacing showed significant differences $(\mathrm{P} \leq 0.05)$ for all yield and yield components studied. The effects of $\mathrm{N}$ rate by inter-row spacing interaction were not significant for some traits studied except for lodging index, biomass, grain, and straw yield and harvest index. Application of $\mathrm{N}$ rate at $97.5 \mathrm{kgha}^{-1}$ and inter-row spacing with $25 \mathrm{~cm}$ significantly $(\mathrm{P} \leq 0.01)$ increased grain yield of teff. Moreover, both $\mathrm{N}$ fertilizer rates and wider inter-row spacing increased the magnitudes of the important yield attributes including plant height, panicle length, number of effective tillers per plant, thousand seed weight, Biomass yield and straw yield significantly $(\mathrm{P} \leq 0.01)$ and also inter-row spacing increased the magnitudes of the important yield attributes including significantly $(\mathrm{P} \leq 0.05)$. From the results of the study it is possible to conclude that increased application of nitrogen fertilizer rate and row spacing improves yield and yield components of teff. Therefore, application of $97.5 \mathrm{~kg} \mathrm{~N} \mathrm{ha}^{-1}$ and inter-row spacing of $25 \mathrm{~cm}$ gave maximum profit which can be recommended for the study area.
\end{abstract}

Keywords: Nitrogen, inter-row spacing; teff; fertilizer rates

DOI: $10.7176 / \mathrm{JNSR} / 11-23-05$

Publication date: December $31^{\text {st }} 2020$

\section{INTRODUCTION}

Teff [Eragrostis teff (Zucc.) Trotter] is the major staple food crop of Ethiopia (Arnold et al., 2008). It has the largest value in terms of both production and consumption in Ethiopia (Minten et al., 2013; Tesfay and Gebresamuel. 2016). Mostly used to prepare a spongy flat bread called "enjera", which is consumed by about $70 \%$ of the Ethiopian people (Debebe, 2005 and Firida, 2016). It is typically hand-broadcasted on the field and, in most cases, seeds are left uncovered (Sate et al., 2016). When grown as a cereal, farmers highly value its straw as source of animals feed, especially during the dry season (Cheng et al., 2017). Teff straw, besides being the most appreciated feed for cattle, it is also used to reinforce mud and plaster the walls of tukuls and local grain storage facilities called gottera (Ketema, 1997; Tesfahun, 2018 and Amare et al., 2015). Moreover, it has got many prospects outside of Ethiopia due to its gluten freeness, tolerance to biotic and abiotic stress, animal feed and erosion control quality (Amare et al., 2015 and Sate et al., 2016). Teff in Ethiopia accounts first in area coverage and second in total annual production next to maize, and ranks the lowest yield compared with other cereals grown in Ethiopia (CSA, 2016 and Tesfahun, 2018). In Ethiopia, it is cultivated on an area of about 2.8 million hectares which taking up about $28.5 \%$ of the total grain crop area (Firdisa, 2016).

In spite of the aforementioned importance its productivity is very low $\left(1.46 \mathrm{t} \mathrm{ha}^{-1}\right)$ as compared to other major cereals (CSA, 2014). Some of the factors contributing to low yield of teff are low soil fertility, suboptimal use of mineral fertilizers, weeds, uneven rainfall distribution in lower altitudes, lack of high yielding cultivars, lodging, water-logging, and low moisture (Ermias et al., 2007). Farmers in Ethiopian highlands apply N fertilizer in the form of Urea at sub-optimal blanket rates mostly only once at the time of sowing, and this limits the potential productivity of cereal crops (Bekele et al., 2000). Farmers in Limo district also apply low amounts of nitrogen only one time at sowing for teff production. In general, blanket recommendations regardless of considering the physical and chemical properties of the soil as well as application of full dose at one time, do not lead to increase 
the teff productivity.

Even if producers do not give attention for teff row spacing, it has an advantage for shorter maturity days, highest plant height and panicle length, more number of tillers and less lodging percentages which helps to improve grain yield of teff (Alemat et al., 2016). Those the above mentioned problems are real challenges in the study area. There is significant reduction of yield of teff in Limo district due to usage of inappropriate row spacing and lack of area specific $\mathrm{N}$ rate application. Therefore, it is a paramount importance and initiated to develop and recommend appropriate row spacing and optimum rate of $\mathrm{N}$ fertilizer for maximizing teff production in the study area.

\section{MATERIALS AND METHODS}

The experiment was conducted at Wachemo University experimental site in Limo district in 2016/2017 cropping season. The area receives a mean annual rainfall of $1800 \mathrm{~mm}$ with mean maximum temperature of $16-24^{\circ} \mathrm{c}$ and minimum of $16^{\circ} \mathrm{c}$ (Fig 1)). Soil physical and chemical properties of the study area (Table 1).

\begin{tabular}{lllll}
\hline \multicolumn{1}{c}{ Parameters } & Value & Rating & Reference & Remark \\
\hline Total nitrogen $(\%)$ & 0.11 & Low & Havlin et al. $(1999)$ & Deficient \\
Available phosphors $\left(\mathrm{mgkg}^{-1}\right)$ & 9.4 & Medium & Olsen et al. $(1954)$ & Sufficient \\
Organic carbon $(\%)$ & 1.24 & low & Roy et al. $(2006)$ & Deficient \\
Organic matter Content & 2.13 & Low & Sahlemedhin $(2000)$ & Deficient \\
pH $\left(\mathrm{H}_{2} 0\right)$ & 6.4 & Slightly Acidic & FAO, 2000 & Suitable \\
$\begin{array}{l}\text { Cation Exchangeable Capacity } \\
\left(\mathrm{meqkg}^{-1}\right)\end{array}$ & 20.4 & Medium & Sahlemedhin (1999) & Sufficient \\
Sand $(\%)$ & & & & \\
Silt $(\%)$ & $26 \%$ & Clay $(\%)$ & $24 \%$ & \\
\hline
\end{tabular}

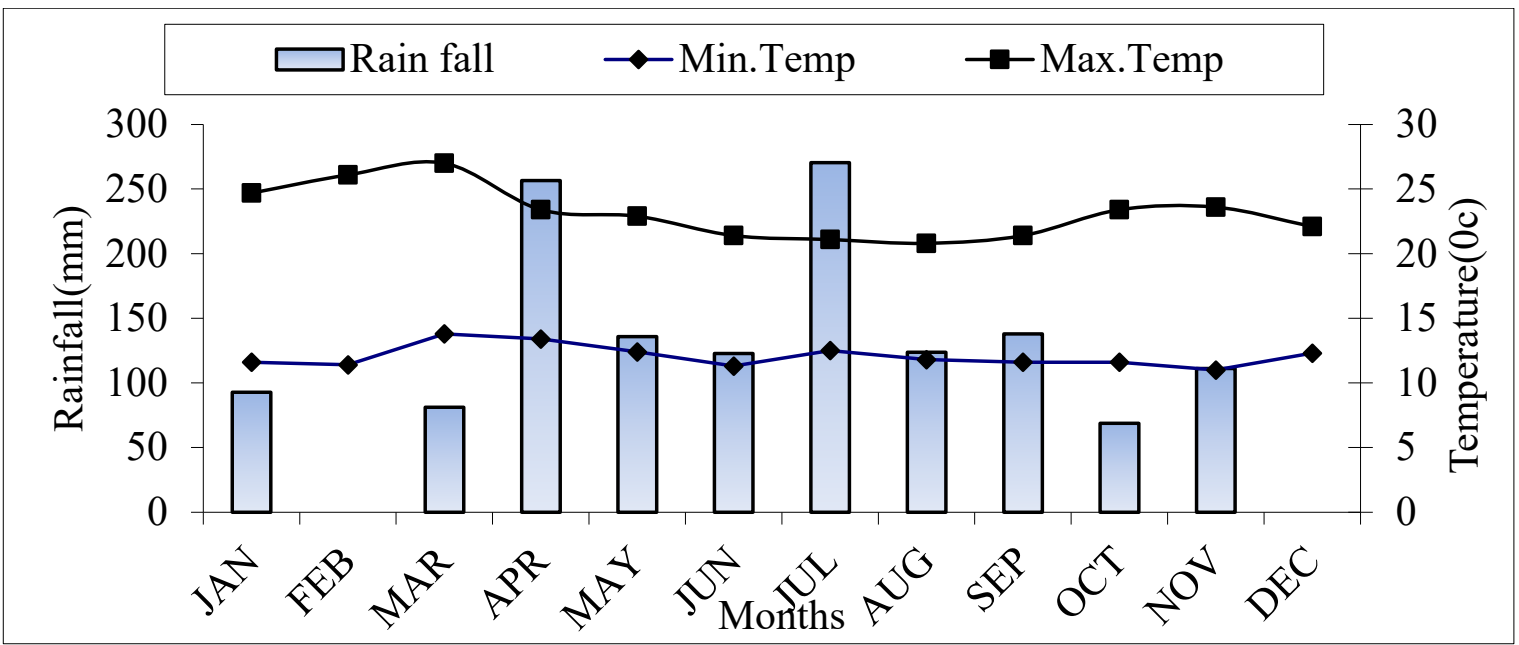

Figure 1. The minimum and maximum Temperature and Mean Rainfall of the experimental area during 2016/2017 year periods (Source: Hawassa Meteorological Data Station (2016/2017))

\section{Treatments and Experimental Materials}

The experiment was designed in factorial randomized complete block design consisting of four levels of $\mathrm{N}$ fertilizer rates $(0,32.5,65$ and $97.5 \mathrm{~kg} / \mathrm{ha})$ and three row spacing $(15,20$ and $25 \mathrm{~cm})$.

Each treatment was replicated three times and there were twelve treatment combinations. Each plot had an area of $1.5 \mathrm{~m} * 2.25 \mathrm{~m}$. The row spacing of 15, 20 and $25 \mathrm{~cm}$ had 15, 11 and 9 rows, respectively. The net plot size was $2.34 \mathrm{~m}^{2}$ and a spacing of 0.5 and $1 \mathrm{~m}$ was maintained respectively between plots and replications. Quncho (Dz-CR-387) teff variety which is released by Debre Zeit Agricultural Research Center was used for the experiment.

\section{Field Management practices}

Land preparation was done according to farmers practice in the area and leveling was carried out by manually to ensure better seedbed for small seeds of teff. All TSP and half of the urea was applied at the time of sowing for row planting. The remaining urea was applied at tillering stage of the crop. This was due to reduce leaching loss of nutrients and to harmonize the supply with the crop demand. Moreover, weeding was done alike to farmers practice in area. 


\section{Soil Sampling and Analysis}

A composite soil sample from the depth of $0-15 \mathrm{~cm}$ was taken independently from 10 representative spots. The soil physio-chemical parameters were analyzed for this study. Soil organic matter was determined by following Walkley and Black method (1934). Soil pH was determined in 1:2.5 soil: water ratio using a glass electrode attached to a digital pH meter. Total $\mathrm{N}$ was determined by Kjeldahl method (Frietal and Dewis, 1970). Available $\mathrm{P}$ was determined by Olsen and Bray II method (1954). Soil Cation exchange capacity was determined by using 1 $\mathrm{M}$ ammonium acetate.

\section{Data Collection and Measurements Phenological Growth Parameters}

Days to panicle emergence was recorded as the number of days from seedling emergence to the time when the tips of panicles at least of ten first emerged from the main shoot in each plot. Days to physiological maturity was taken as the number of days elapsed from seedling emergence to the date when $90 \%$ of the crop stems, leaves and floral parts in a plot changed to light yellow color. Plant height was measured as the height of plants in centimeter from the base of the main stem to the tip of the panicle and recorded as the average of ten randomly selected plants. Panicle length was measured as the length of the panicle in centimeter of the main shoot from the node where the first panicle branch starts to the tip of the panicle as the average of ten randomly selected plants at physiological maturity.

\section{Yield and Yield Components}

Number of fertile tillers was counted including the main shoot from an area of ten randomly selected plants from each plot. 1000-seed weight was determined by taking 1000 seed from each plot using sensitive balance. Grain yield was recorded as the weight of the air-dried seeds harvested from net plot size of each plot in $\mathrm{kg}$. For analysis $\mathrm{g} / \mathrm{plot}$ was converted to $\mathrm{kg} / \mathrm{ha}$.

Straw yield was determined by subtracting grain yield from above ground dry biomass yield. Biomass yield at maturity, the whole plant parts, including leaves and stems, and seeds from the net plot area was harvested and after drying, the biomass was measured. Harvest index was recorded as the ratio of grain yield to shoot biomass at harvest in $\mathrm{kg}$ from net plot.

\section{Lodging Percentage}

The degree of lodging was assessed just before the time of harvesting by visual observation based on the scales of 1-5. Where 1 (0-15\%) indicates no lodging and 5 (60-90\%) indicates 100\% lodging (Donald, 2004). The scales were determined by the angle of inclination of the main stem from the vertical line to the base of the stem by visual observation.

\section{Statistical Data Analysis}

The Data were subjected to analysis of variance (ANOVA) procedures by using SAS version 9.3 with a general linear model procedure. Mean separation (mean differences comparison) was undertaken by Duncan's Multiple Range Test (Duncan, 1955) at 5 percent level of probability.

A correlation analysis was carried out by calculating simple correlation coefficients between among the parameters by using SAS software. Economic analysis was done using CIMMYT partial budget Methodology (CIMMYT, 1988)

\section{RESULTS AND DISCUSSIONS}

\section{Days to 50 \% Panicle Emergence}

Days to panicle emergence were significantly $(\mathrm{P}<0.01)$ affected by the main effects but their interaction was not significantly $(\mathrm{P}>0.05)$ different (Table 1$)$.

Application of $\mathrm{N}$ at $97.5 \mathrm{~kg} \mathrm{ha}^{-1}$ significantly delay panicle emergence than that of the other treatments (Table 1). The prolonged in days to panicle emergence due to $\mathrm{N}$ application might be high $\mathrm{N}$ levels promoted excessive vegetative growth and development of the plants possibly due to synchrony of the time of need of the plant for uptake of the nutrient and availability of the nutrient in the soil. This result in coherent with the findings of Haftamu et al. (2009) reported that significantly prolonged number of days to heading in response to $\mathrm{N}$ application. Similarly, panicle emergence was also significantly delayed with the successive enlarge in row spacing (Table 1). The earlier in panicle emergence due to slender row spacing might be reduced rate of photosynthesis because of the competition of plants for light, space, nutrients and water. In conformity with the present study, Gorgy (2010) reported one day earlier panicle emergence in plots with $15 \mathrm{~cm}$ than with $25 \mathrm{~cm}$ row spacing.

\section{Days to physiological Maturity}

Days to $90 \%$ maturity were significantly $(\mathrm{P}<0.01)$ affected by the main effects but their interaction effect were not 
significantly $(\mathrm{P}>0.05)$ different (Table 1$)$.

Application of high rate $\mathrm{N}$ delayed maturity in teff which was significant with the increase in nitrogen application rates (Table 1). Hence, it was postponed by twenty-seven days in response to receiving $97.5 \mathrm{~kg} \mathrm{~N} \mathrm{ha}^{-1}$ than that of the control treatment (Table 1). This might be attributed from the formation of chlorophyll which keeps the plant photosynthetically active for longer period. This result in coherent with the findings of Temesgen (2001) found that high $\mathrm{N}$ application rates caused physiological maturity to delay due to the direct effect of $\mathrm{N}$ on vegetative growth in tef.

Physiological maturity was significantly earlier at the closer inter-row spacing of $15 \mathrm{~cm}$ than 20 and $25 \mathrm{~cm}$ row spacing (Table 2). The earlier in physiological maturity due to closer row spacing might be the presence of intense inter-space competition which led to depletion of the available nutrient and as a results plants tended to mature earlier. The current finding was in proportion to the work of Wubante et al., (2017) who concluded that plants grown at $15 \mathrm{~cm}$ row spacing significantly shortened days to $90 \%$ physiological maturity than those grown at the wider row spacing.

\section{Plant Height}

Plant Height were significantly $(\mathrm{P}<0.01)$ affected by the main effects but their interaction was not significantly $(\mathrm{P}>0.05)$ different (Table 1).

The plants attained significantly maximum plant height with the further increase in $\mathrm{N}$ application rate. Thus, the highest plants height $(125.02 \mathrm{~cm})$ were obtained with the application of $97.5 \mathrm{~kg} \mathrm{~N}^{-1}$ which was $39.5 \%$, $26.23 \%$ and $8 \%$ greater than the control, 32.5, $65 \mathrm{~kg} \mathrm{~N} \mathrm{ha}^{-1}$, respectively (Table 1). This may be characterized that $\mathrm{N}$ usually favours vegetative growth of teff, happening in higher status of the plants with tallest plant height. In line with this results, Haftamu et al. (2009) described that teff with upper plant height was obtained by applying maximum amount of Nitrogen rate.

The inter row spacing of $25 \mathrm{~cm}$ resulted in significantly higher plant height $(103.82 \mathrm{~cm})$ than $15 \mathrm{~cm}$ row spacing. The plants in $25 \mathrm{~cm}$ row spacing were $4 \%$ and $1.18 \%$ taller than the plants in 15 and $20 \mathrm{~cm}$ row spacing, respectively (Table 1). This might be less competition of crops for nutrients which providing better environment for growth and development of crop. Similarly, Mahato et al. (2007) reported that maximum plant height was obtained with wider spacing as compared to closer spacing in rice.

Table 1 . Days to $50 \%$ panicle emergence, days to $90 \%$ physiological maturity and plant height were influenced by nitrogen fertilizer rates and inter-row spacing on teff in Limo district, SNNPR in 2016/2017 main cropping season

\begin{tabular}{cccc}
\hline Main Effect & PE & PM & PH \\
\hline N- rate (Kg/ha) & & & $75.82^{\mathrm{d}}$ \\
\hline 0 & $55.3^{\mathrm{d}}$ & $99.4^{\mathrm{d}}$ & $92.23^{\mathrm{c}}$ \\
65 & $60.5^{\mathrm{c}}$ & $107.3^{\mathrm{c}}$ & $114.96^{\mathrm{b}}$ \\
97.5 & $67.2^{\mathrm{b}}$ & $117.5^{\mathrm{b}}$ & $125.02^{\mathrm{a}}$ \\
\hline LCD & $71.4^{\mathrm{a}}$ & $126.4^{\mathrm{a}}$ & $3.842^{\mathrm{a}}$ \\
\hline Row Spacing (cm) & 2.134 & 3.916 & $99.6^{\mathrm{b}}$ \\
\hline 15 & & & $102.59^{\mathrm{ba}}$ \\
20 & $61.25^{\mathrm{b}}$ & $108.16^{\mathrm{b}}$ & $103.82^{\mathrm{a}}$ \\
\hline LCD & $64.58^{\mathrm{a}}$ & $114.58^{\mathrm{a}}$ & 3.328 \\
CV (\%) & $64.92^{\mathrm{a}}$ & $115.08^{\mathrm{a}}$ & 3.85 \\
\hline
\end{tabular}

LCR: Means of Least Critical range; CV: Coefficient of Variance, PE: Panicle Emergence, PM: Physiological Maturity, PH: Plant Height

Means within the same column and within the same treatment category followed by the same superscript letters are not significantly different as judged by DMRT at $\mathbf{P} \leq \mathbf{0 . 0 5}$.

\section{Panicle Length}

The analysis of variance indicated that the main effect of nitrogen fertilizer rates was highly significantly $(\mathrm{P} \leq 0.01)$ affected panicle length and also row spacing was significantly $(\mathrm{P} \leq 0.05)$ influenced panicle length. However, the interaction factors were not significantly $(\mathrm{P} \geq 0.05)$ different (Table 2$)$.

Panicle length is one of the yield attributes of that contribute to grain yield. An increase of rate of $\mathrm{N}$ application increased the panicle length of teff. Thus, the maximum panicle length (44.9) was recorded when 97.5 $\mathrm{kg} \mathrm{ha}^{-1} \mathrm{~N}$ was applied which was $23.4 \%, 16.35 \%$ and $8.9 \%$ higher than the control treatment, 32.5 and $65 \mathrm{~kg} \mathrm{~N}$ $\mathrm{ha}^{-1}$, respectively (Table 2). Having long panicle is directly related with yield of teff. The increment in panicle length due to higher $\mathrm{N}$ application might be the better $\mathrm{N}$ position of plant during panicle growth period. Consistent 
with this results, Awan et al. (2011) reported the highest panicle length found in treatments receiving higher nitrogen rates.

The outcome of this study showed that wider inter-row spacing $(25$ and $20 \mathrm{~cm})$ led to significantly higher panicle length than the closer spacing of $15 \mathrm{~cm}$ inter-row spacing (Table 2). The improvement in panicle length due to wider row spacing probably due to the more availability of growth resource might be in increase in chlorophyll formation. Consistent this study, Hasanuzzaman et al. (2009) reported the higher number of tillers obtained in the widely spaced plants was more effective in mobilizing photosynthates for panicle length and grain filling compared to closely spaced plants resulting in higher number of panicle length.

\section{Number of Fertile Tillers}

Number of fertile tillers were significantly $(\mathrm{P}<0.01)$ affected by the main effects but their interaction was not significantly $(\mathrm{P}>0.05)$ different (Table 2$)$.

In the current study, it was found that with the successive increase in nitrogen application rates, the number of effective tillers also increased significantly. The maximum numbers of effective tillers (13.79) were obtained with the application of $97.5 \mathrm{~kg} \mathrm{~N} \mathrm{ha}^{-1}$ which was higher by $56.3,38.22$ and $11.53 \%$, over the control treatment, 32.5 , and $65 \mathrm{~kg} \mathrm{~N} \mathrm{ha}^{-1}$, respectively (Table 2). This might be obtained due to the more availability of $\mathrm{N}$ that might have played a vital role in cell division. Consistent with these results, Haftamu et al. (2009) reported significantly maximum number of tillers in response to the application of high $\mathrm{N}$ rate in tef.

Increasing row spacing from $15 \mathrm{~cm}$ to $25 \mathrm{~cm}$ increased the number of effective tillers. However, the number was significantly greater with 20 and $25 \mathrm{~cm}$ row spacing than with $15 \mathrm{~cm}$ row spacing. However, no significant differences were observed between 20 and $25 \mathrm{~cm}$ inter-row spacing. The increase in the number of effective tillers with 20 and $25 \mathrm{~cm}$ was $18.9 \%$ and $21.5 \%$, respectively over $15 \mathrm{~cm}$ row spacing (Table 2). This may probably due to better access to space, nutrient, water and light in wider spacing. Similarly, Sultana et al. (2012) found the highest number of effective tillers with $25 \mathrm{~cm}$ row spacing in rice.

\section{Thousand Seed weight}

Thousand seed weight were significantly $(\mathrm{P}<0.01)$ affected by the main effects but their interaction was not significantly $(\mathrm{P}>0.05)$ different (Table 2$)$.

This study indicated that application of nitrogen rate influenced thousand seed weight. The highest thousand seed weight $(0.388 \mathrm{gm})$ was recorded at $\mathrm{N}$ rate $65 \mathrm{~kg} / \mathrm{ha}$ and the lowest $(0.284 \mathrm{gm})$ was recorded from the control treatment (Table 3). However, these nitrogen rates had significantly higher thousand seed weight than that of the control treatment. The improve in 1000 Seed weight due to $\mathrm{N}$ application rate might be the increase in chlorophyll concentration which led to higher photosynthetic rate for grain development and then, reduce with further application of $\mathrm{N}$ rate (Table 2). In line with this results, Ahmed et al. (2005) who found that weight of 1000-grains was maximum when nitrogen applied at a rate of $40 \mathrm{~kg} \mathrm{ha}^{-1}$ in rice.

The results showed that with the increase in inter-row spacing the thousand seed weight also increased slightly. Thousand seed weight was slightly maximums at $25 \mathrm{~cm}$ inter-row spacing as compared to $20 \mathrm{~cm}$ but statistically no significant difference between them. However, the lowest 1000 -seed weight was recorded at $15 \mathrm{~cm}$ inter-row spacing (Table 3). Higher 1000-seed weight noted in wider rows might be efficient utilization of water, nutrients and light due to minimal inter-rows competition and lower plant population in teff. The results are in line with that of Alamat et al. (2012) who obtained increased grain weight at wider row spacing $(22.5 \mathrm{~cm})$ in teff.

Table 2. Panicle length (cm), effective tillers (№) and thousand seed weight (gm)were influenced by nitrogen fertilizer rates and inter-row spacing on teff in Limo district, SNNPR in 2016/2017 main cropping season

\begin{tabular}{cccc}
\hline Main Effect & PL & ET & TSW \\
\hline N-Rates (Kg/ha) & & & $0.284^{\mathrm{d}}$ \\
\hline 0 & $34.39^{\mathrm{d}}$ & $6.02^{\mathrm{d}}$ & $0.334^{\mathrm{b}}$ \\
65 & $37.56^{\mathrm{c}}$ & $8.52^{\mathrm{c}}$ & $0.388^{\mathrm{a}}$ \\
97.5 & $40.9^{\mathrm{b}}$ & $12.2^{\mathrm{b}}$ & $0.358^{\mathrm{b}}$ \\
\hline LCR & $44.9^{\mathrm{a}}$ & $13.79^{\mathrm{a}}$ & 0.02611 \\
\hline Row Spacing (cm) & 2.474 & 1.293 & $0.306^{\mathrm{b}}$ \\
\hline 15 & & & $0.357^{\mathrm{a}}$ \\
25 & $37.63^{\mathrm{b}}$ & $8.65^{\mathrm{b}}$ & $0.368^{\mathrm{a}}$ \\
\hline LCR & $39.96^{\mathrm{a}}$ & $10.67^{\mathrm{a}}$ & 0.02261 \\
CV (\%) & $40.74^{\mathrm{a}}$ & $11.02^{\mathrm{a}}$ & 8.28 \\
\hline
\end{tabular}

LCR: Means of Least Critical range; CV: Coefficient of Variance, PL: Panicle Length, ET: Effective Tillers, TSW: Thousand Seed Weight

Means followed by the same superscript letters are not significantly different as judged by DMRT at P $\leq 0.05$. 


\section{Biomass Yield}

Biomass yield were significantly $(\mathrm{P}<0.01)$ influenced by both the main as well as by interaction effects (Table 3 ). Biomass yield generally increased highly significantly $(\mathrm{P} \leq 0.01)$ with the increase in the rate of nitrogen across the increasing inter-row spacing. The highest biomass yield $(1313.3 \mathrm{Kg} / \mathrm{ha})$ was found from a combination of $97.5 \mathrm{~kg}$ $\mathrm{N} \mathrm{ha}^{-1}$ with $25 \mathrm{~cm}$ row spacing. Whereas, the lowest biomass yield $(8046.7 \mathrm{~kg} / \mathrm{ha})$ was obtained from a combination of control with $15 \mathrm{~cm}$ inter-row spacing (Table 3). Hence, further increase in $\mathrm{N}$ rates and wider row spacing the aboveground dry biomass yield increased significantly.

The main effect of $\mathrm{N}$ fertilizer rates was highly significantly $(\mathrm{P} \leq 0.01)$ affected biomass yield of teff. The highest biomass yield (12607.78) was achieved from $97.5 \mathrm{~kg} \mathrm{~N} \mathrm{ha}^{-1}$ application. Whereas, the lowest biomass (8374.44) was obtained from control treatment (Table 3). In general, the further increase in nitrogen fertilizer rate increased the biomass yield of teff. Similar results were reported by Dutta et al. (2002) who found the highest biomass yield by applying high $\mathrm{N} \mathrm{ha}^{-1}$. The increment in biomass yield due to high nitrogen might be high $\mathrm{N}$ application positively causes high vegetative growth, and enlargement of stem cells that consequently increased biomass yield.

Row spacing was highly significantly $(\mathrm{P} \leq 0.01)$ affected biomass yield of teff. The highest biomass yield (10970.8) was observed from plants that planted at $25 \mathrm{~cm}$ inter-row spacing and the lowest biomass yield (10227.5) was obtained from $15 \mathrm{~cm}$ inter-row spacing followed by $20 \mathrm{~cm}$ (Table 3). In general, further increase in inter-row spacing increased biomass yield. The increase in aboveground dry biomass in response to increasing (widening) the inter-row spacing might be due the better environment for growth and development of crop that might be resulted in improved plant height, more number of effective tillers and panicle length (Table 1and 2). Ali et al. (2011) also found increased biomass yield with wider inter-row spacing due to higher production of tillers in rice.

\section{Grain Yield}

Grain yield were significantly $(\mathrm{P}<0.01)$ affected by both by the main as well as by interaction effects (Table 3$)$. The interaction effects of nitrogen fertilizer rates and row spacing were highly significantly $(\mathrm{P} \leq 0.01)$ affected grain yield of teff. The highest grain yield ( $3403.3 \mathrm{~kg} / \mathrm{ha})$ was observed from a combination of $97.5 \mathrm{~kg} \mathrm{~N} \mathrm{ha}^{-1}$ with 25 $\mathrm{cm}$ inter-row spacing. While the minimum grain yield $(1690 \mathrm{~kg} / \mathrm{ha})$ was observed from the control treatment with $15 \mathrm{~cm}$ inter-row spacing (Table 3). In general, further increase in $\mathrm{N}$ rate and row spacing increased grain yield of teff. Increase in grain yield due to the application of nitrogen rate and wider row spacing might have been due to improvement of yield contributing characters like number of effective tillers and panicle length (Table 2). Therefore, the higher the number of tillers, especially fertile tillers, the more will be the yield.

Grain yield was highly significantly $(\mathrm{P} \leq 0.01)$ affected by the main effects of nitrogen fertilizer rates. The highest grain yield (3148.89) was obtained from plants that supplied with $97.5 \mathrm{~kg} \mathrm{~N} \mathrm{ha}^{-1}$ and the lowest grain yield (2065.56) was obtained from control. However, there was no significant different between 32.5 and $65 \mathrm{~kg} \mathrm{~N}^{-1}$ (Table 3). In general, further increase in nitrogen fertilizer rates increased grain yield of teff. Increased grain yield due to increased $\mathrm{N}$ application was also reported for different cereal crops. Nitrogen supply directly or indirectly affects chlorophyll content, LAI, canopy coverage and other biophysical parameters (Serrano et al., 2000).

Likewise, the main effect of row spacing was highly significantly $(\mathrm{P} \leq 0.01)$ affected grain yield of teff. The highest grain yield (2886.67and 2839.17) was obtained from plants that planted at 20 and $25 \mathrm{~cm}$ row spacing, respectively. However, the lowest (2453.3) was obtained from $15 \mathrm{~cm}$ row spacing (Table 3). The results of this study was in line with that of Sultana et al. (2012) who reported that yields of cereals increased as the spacing between rows increased because plant populations are normally high in narrow spacing $(15 \mathrm{~cm})$.

Table 3. Grain yield (Kg/ha) were affected by interaction as well as by the main effects of nitrogen rates and interrow spacing in Limo District, SNNPR in 2016/2017 main cropping season

\begin{tabular}{|c|c|c|c|c|c|c|c|c|}
\hline \multirow{3}{*}{$\begin{array}{l}\text { N- Rate } \\
(\mathrm{Kg} / \mathrm{ha})\end{array}$} & \multicolumn{3}{|c|}{$\mathrm{BY}$} & \multicolumn{5}{|c|}{ GY } \\
\hline & \multicolumn{3}{|c|}{ Row Spacing $(\mathrm{cm})$} & \multirow[b]{2}{*}{ Mean } & \multicolumn{3}{|c|}{ Row Spacing (cmx) } & \multirow[b]{2}{*}{ Mean } \\
\hline & 15 & 20 & 25 & & 15 & 20 & 25 & \\
\hline 0 & $8046.7^{\mathrm{i}}$ & $8423.3^{h}$ & $8653.3^{h}$ & $8374.44^{\mathrm{d}}$ & $1690.00^{\mathrm{h}}$ & $2173.3^{g}$ & $2360.0^{f}$ & $2065.56^{d}$ \\
\hline 32.5 & $9500.0^{\mathrm{g}}$ & $10160.0^{f}$ & $10476.7^{\mathrm{e}}$ & $10045.56^{\mathrm{c}}$ & $2436.67^{f}$ & $2816.7^{\mathrm{e}}$ & $2860.0^{\mathrm{ed}}$ & $2788.89^{b}$ \\
\hline 65 & $11336.7^{\mathrm{d}}$ & $11313.3^{\mathrm{d}}$ & $11580.0^{\mathrm{d}}$ & $11410.00^{\mathrm{b}}$ & $2883.3^{\text {ed }}$ & $3103.3^{\mathrm{cb}}$ & $3176.7^{b}$ & $3148.89^{a}$ \\
\hline 97.5 & $12026.7^{\mathrm{c}}$ & $12623.3^{b}$ & $13173.3^{\mathrm{a}}$ & $12607.78^{\mathrm{a}}$ & $3000.0^{\mathrm{cd}}$ & $3166.7^{\mathrm{b}}$ & $3403.3^{\mathrm{a}}$ & $2902.22^{b}$ \\
\hline Mean & $10227.5^{c}$ & $10630^{b}$ & $10970.8^{\mathrm{a}}$ & & $2453.3^{b}$ & $2886.67^{\mathrm{a}}$ & $2839.17^{\mathrm{a}}$ & \\
\hline LCR & & 306.1 & & & 156.2 & & & \\
\hline $\mathrm{CV}(\%)$ & & 1.7 & & & 3.35 & & & \\
\hline
\end{tabular}




\section{Straw Yield}

Straw yield was affected significantly $(\mathrm{P}<0.01)$ by both by the main as well as by interaction effects $($ Table 4$)$. The interaction effects of nitrogen fertilizer rates and row spacing were significantly $(\mathrm{P} \leq 0.01)$ affected straw yield of teff. The highest straw yield $(9770 \mathrm{~kg} / \mathrm{ha})$ was obtained from crops that were applied at rate of $97.5 \mathrm{~kg} \mathrm{~N} \mathrm{ha}^{-1}$ with $25 \mathrm{~cm}$ inter-row spacing and this is statistically parity at $97.5 \mathrm{~kg} \mathrm{~N} \mathrm{ha}^{-1}$ with the $20 \mathrm{~cm}$ row spacing (9456.7 $\mathrm{kg} / \mathrm{ha})$. While the lowest straw yield $(6250 \mathrm{~kg} / \mathrm{ha})$ was obtained from the control with $20 \mathrm{~cm}$ inter-row spacing (Table 4). From this study, the straw yield increased significantly with increase in the rate of nitrogen application and inter-row spacing. The higher straw yield at higher $\mathrm{N}$ rates and wider inter-row spacing that could probably be the outcome of more leaf area, higher interception of solar energy and high absorption of nutrients which might have brought about higher photosynthetic efficiency dry matter production.

Straw yield was highly significantly $(\mathrm{P} \leq 0.01)$ affected by the main effects of nitrogen fertilizer rate. The highest straw yield (9705.56) was attained from plants that supplied with $97.5 \mathrm{~kg} \mathrm{~N} \mathrm{ha}^{-1}$ and the lowest was obtained from control treatment (Table 4). Similar with the results of this study, Rahman et al. (2000) reported that nitrogen influenced vegetative growth in terms of plant height and number of tillers (Table 1 and 2) which resulted in increased straw yield (Table 4). The increase in straw yield in response to the application of $\mathrm{N}$ fertilizer might be due to greater availability and uptake of the nutrient by plants, and the resulting induction of vigorous vegetative growth with more leaf area resulting in higher photosynthesis and assimilates production and dry matter accumulation (Islam et al., 2008).

The main effect of row spacing was highly significantly $(\mathrm{P} \leq 0.01)$ affected straw yield. The highest straw yield (8131.67) was obtained from plants that planted at $25 \mathrm{~cm}$ row spacing and the lowest straw yield (7774.17 and 7743.3) was obtained from plants that sown at 15 and $20 \mathrm{~cm}$ row spacing, respectively. However, there is no significant different between 15 and $20 \mathrm{~cm}$ row spacing (Table 4). In general, further increase in row spacing increased the straw yield of teff. The highest straw yield obtained from wider row spacing might be wider spacing due to higher production of plant height and effective tillers. This result agrees with Yordanos (2013), that the straw yield was significantly influenced by the successive increase in row spacing.

\section{Harvest Index}

Harvest index were significantly $(\mathrm{P}<0.01)$ affected by both main as well as by interaction effects (Table 4).

The interaction effect of $\mathrm{N}$ fertilizer rates and row spacing were highly significantly $(\mathrm{P} \leq 0.01)$ affected harvest index. Thus, the maximum harvest index $(27.7 \%)$ was obtained from plants that were supplied nitrogen fertilizer rate of $32.2 \mathrm{~kg} \mathrm{~N} \mathrm{ha}^{-1}$ with $20 \mathrm{~cm}$. whereas, the lowest harvest index $(21.00 \%)$ was observed from the control with $15 \mathrm{~cm}$ inter row spacing (Table 4). The data suggested that nitrogen levels from 65 to $97.5 \mathrm{~kg} / \mathrm{ha}^{-1}$ decreased the harvest index (Table 4). The maximum harvest index obtained from the more or less increase in $\mathrm{N}$ application and then decreased with extra increase in $\mathrm{N}$ rates, this might be minor biomass partitioning to grain production. This finding was in covenant with those of Hasanuzzaman et al. (2009) and Yoseftabar (2013) who obtained higher harvest index in rice with the more or less increased $\mathrm{N}$ rates and decreased with further increase in $\mathrm{N}$ application.

Harvest index was highly significantly $(\mathrm{P} \leq 0.01)$ affected by the main effects of nitrogen fertilizer rate. The highest harvest index (27.68 and 27.61) was obtained from plants that supplied 32.5 and $65 \mathrm{~kg} \mathrm{~N} \mathrm{ha}^{-1}$, respectively. The lowest harvest index was obtained from plants that supplied nitrogen at $97.5 \mathrm{~kg} \mathrm{ha}^{-1}$ (Table 4). In general, further increase in $\mathrm{N}$ rate decreased harvest index. This finding was in agreement with those of Mahato et al. (2007) who obtained higher harvest index in rice with the more or less increased nitrogen application rates and decreased finally with further increase in application of nitrogen fertilizer.

Likewise, row spacing was also highly significantly $(\mathrm{P} \leq 0.01)$ affected harvest index. The maximum harvest index (27.27 and 26.185) was obtained from plants that planted at 20 and $25 \mathrm{~cm}$ row spacing, respectively. The minimum harvest index (23.77) was obtained from $15 \mathrm{~cm}$ row spacing (Table 4). In general, further increase in row spacing increased harvest index. The increment in harvest index due to wider row spacing might be less intraspecific competition led to greater proportional increase in grain yield than biomass accumulation. Similarly, Hussain et al. (2012) who found that higher harvest index was reported in $20 \mathrm{~cm}$ row spacing, but statistically similar with $25 \mathrm{~cm}$ row spacing in wheat crop. 
Table 4. Straw yield $(\mathrm{Kg} / \mathrm{ha})$ and Harvest Index $(\%)$ were affected by interaction as well as by the main effects of nitrogen rates and inter-row spacing in Limo District, SNNPR in 2016/2017 main cropping season

\begin{tabular}{|c|c|c|c|c|c|c|c|c|}
\hline \multirow{3}{*}{$\begin{array}{l}\text { N- Rate } \\
\text { (Kg/ha) }\end{array}$} & \multicolumn{3}{|c|}{ SY } & \multicolumn{5}{|c|}{$\mathrm{HI}$} \\
\hline & \multicolumn{3}{|c|}{ Row Spacing (cm) } & & \multicolumn{3}{|c|}{ Row Spacing (cm) } & \multirow[b]{2}{*}{ Mean } \\
\hline & 15 & 20 & 25 & Mean & 15 & 20 & 25 & \\
\hline 0 & $6356.7^{f}$ & $6250.0^{f}$ & $6293.3^{f}$ & $6308.89^{d}$ & $21.00^{\mathrm{d}}$ & $25.8^{b c}$ & $27.4^{\text {ba }}$ & $24.5956^{b}$ \\
\hline 32.5 & $7063.3^{\mathrm{e}}$ & $7343.3^{\mathrm{ed}}$ & $7616.7^{\mathrm{d}}$ & $7256.67^{\mathrm{c}}$ & $25.67^{b c}$ & $27.7^{\mathrm{a}}$ & $27.3^{\mathrm{ba}}$ & $27.6800^{\mathrm{a}}$ \\
\hline 65 & $8453.3^{c}$ & $8210.0^{\mathrm{c}}$ & $8403.3^{c}$ & $8261.11^{\mathrm{b}}$ & $25.4^{\mathrm{c}}$ & $27.4^{\mathrm{ba}}$ & $27.42^{\text {ba }}$ & $27.6100^{\mathrm{a}}$ \\
\hline 97.5 & $9026.7^{b}$ & $9456.7^{\mathrm{a}}$ & $9770.0^{\mathrm{a}}$ & $9705.56^{a}$ & $24.9^{c}$ & $25.08^{c}$ & $25.85^{b c}$ & $23.0789^{\mathrm{c}}$ \\
\hline Mean & $7774.17^{b}$ & $7743.3^{b}$ & $8131.67^{a}$ & & $23.77^{b}$ & $27.27^{\mathrm{a}}$ & $26.185^{\mathrm{a}}$ & \\
\hline LCR & & 317.3 & & & & 1.634 & & \\
\hline $\mathrm{CV}(\%)$ & & 2.39 & & & & 3.72 & & \\
\hline
\end{tabular}

LCR: Means of Least Critical range; CV: Coefficient of Variance; SY: Straw Yield, HI: Harvest Index Means within the same column and within the same treatment category followed by the same superscript letters are not significantly different as judged by DMRT at $\mathbf{P} \leq \mathbf{0 . 0 5}$

\section{Lodging Index}

The main as well as interaction effects were significantly $(\mathrm{P}<0.01)$ influenced lodging index (Table 5).

The interaction effects of nitrogen fertilizer rates and row spacing were highly significantly influenced lodging index. The highest lodging index was observed from crops that a nitrogen applied at the rate of $97.5 \mathrm{kgha}^{-}$ ${ }^{1}$ with $15 \mathrm{~cm}(57.17 \%)$ inter-row spacing. Whereas, the lowest was obtained from control with $20 \mathrm{~cm}(41.13 \%)$ row spacing and this is statistically parity with control with $25 \mathrm{~cm}(41.43 \%)$ inter row spacing (Table 5).

The main effect of $\mathrm{N}$ fertilizer rates was highly significantly $(\mathrm{P} \leq 0.01)$ influenced lodging index. The highest lodging index (54.9) was obtained from plants that supplied with $97.5 \mathrm{kgNha}^{-1}$ and the lowest (41.9) was obtained from the control (Table 5). In general, further increase in $\mathrm{N}$ application rates increased the lodging index of teff. This could be due to the profound effect of high $\mathrm{N}$ supply on increasing vegetative growth thereby leading to bending of the weak stem of the plant due to the sheer load of the canopy. Similarly, Temesgen et al. (2000) obtained significant differences in lodging percentage of tef due to $\mathrm{N}$ application.

Likewise, the main effect of row spacing was significantly affected lodging index. The highest lodging index (49.45) was recorded from plants that planted at $15 \mathrm{~cm}$ row spacing and the lowest lodging index (48.63) was noted from plants that planted at $25 \mathrm{~cm}$ inter-row spacing followed by $20 \mathrm{~cm}$ (Table 5). The highest lodging index due to narrow spacing might be resulting in dense crop population and slight stem. The present result is in agreement with Alemat et al. (2016) who reported that row spacing for teff showed highly significant differences on lodging when there is narrow in row spacing there was an increase in lodging percentage.

Table 5. Lodging index (\%) were affected by interaction as well as by the main effects of nitrogen rates and interrow spacing in Limo District, SNNPR in 2016/2017 main cropping season

\begin{tabular}{ccccc}
\hline & \multicolumn{5}{c}{ LI } & Means of overall N-Rate \\
\hline N- Rate $(\mathrm{Kg} / \mathrm{ha})$ & \multicolumn{4}{c}{ Row Spacing $(\mathrm{cm})$} \\
0 & 45 & 20 & 25 & $41.9^{\mathrm{d}}$ \\
32.5 & $49.2^{\mathrm{g}}$ & $41.13^{\mathrm{h}}$ & $41.4^{\mathrm{h}}$ & $46.65^{\mathrm{c}}$ \\
65 & $45.8^{\mathrm{f}}$ & $45.2^{\mathrm{f}}$ & $51.16^{\mathrm{b}}$ \\
97.5 & $48.5^{\mathrm{e}}$ & $50.4^{\mathrm{d}}$ & $54.6^{\mathrm{b}}$ & $54.9^{\mathrm{a}}$ \\
\hline Means of overall Spacing & $57.4^{\mathrm{a}}$ & $54.2^{\mathrm{cb}}$ & $53.3^{\mathrm{c}}$ & \\
\hline LCD & $49.45^{\mathrm{a}}$ & $47.88^{\mathrm{c}}$ & $48.63^{\mathrm{b}}$ & \\
CV (\%) & \multicolumn{5}{c}{} \\
\hline
\end{tabular}

LCR: Means of Least Critical range; CV: Coefficient of Variance; LI: Lodging Index

Means within the same column and within the same treatment category followed by the same superscript letters are not significantly different as judged by DMRT at $\mathbf{P} \leq \mathbf{0 . 0 5}$

\section{SUMMARY AND CONCLUSION}

Teff is one of the most significant staple foods of Ethiopia, but production is not satisfactory due to various factors like lack of blanket recommendation of $\mathrm{N}$ rates and row spacing in the region. A field experiment was carried out during the cropping season of 2016/2017 at the Wachemo University experimental site in Southern Ethiopia with the objective of determining the effects of $\mathrm{N}$ fertilizer rate and inter-row spacing on yield and yield components of teff. The combinations of four levels of $\mathrm{N}(0,32.5,65$ and $97.5 \mathrm{kgN} / \mathrm{ha})$ and three rows spacing $(15,20$ and 25 $\mathrm{cm})$ were used as treatments.

Application of nitrogen and row spacing significantly influenced most of the plant phenology, growth 
parameters, yield and yield components of teff. Thus, the highest dose, i.e. $97.5 \mathrm{~kg} \mathrm{~N} / \mathrm{ha}$ and wider spacing (25 $\mathrm{cm}$ ) proved to be superior to the others dose with respect to enhancing most of these attributes/characters of the teff.

Generally, the study revealed that the teff crop responded more to $\mathrm{N}$ fertilization and wider row spacing. This shows that $97.5 \mathrm{~kg} \mathrm{~N} / \mathrm{ha}$ and $25 \mathrm{~cm}$ row spacing should be employed to increase the productivity of the crop rather than using $65 \mathrm{~N} \mathrm{~kg} / \mathrm{ha}$ and $20 \mathrm{~cm}$ row spacing currently used in the study area. Therefore, taking the finding of the present study into consideration, it may be tentatively concluded that farmers in Hadiya region may apply a combination of $97.5 \mathrm{~kg} \mathrm{~N} \mathrm{ha}^{-1}$ with $25 \mathrm{~cm}$ row spacing to improve the grain yield of teff. Due attention need to be given to the following issue and direction in the future research programme: the present experiment has to be conducted for four seasons across locations of similar agroecology and soil type for recommendation of the appropriate $\mathrm{N}$ dose and row spacing on teff.

\section{REFERENCES}

Ahmed, M., M. Islam, Paul. S.K. 2005. Effect of nitrogen on yield and other plant characters of local rice, Research Journal of Agriculture and Biological Sciences, 1(2):158-161.

Alam,M. Z., Haider,S. A. and Paul.N. K., 2005. Effects of sowing time and nitrogen fertilizer on barley (Hordeum vulgare L.). Bangladesh Journal Boanyt 34: 27-30.

Alemat E, Kidu G/Mesekel, Mihreteab H/Selasie and Haftamu H/kiros. 2016. Determination of the Optimum Population Density of Seedlings during Transplanting for the Productivity Improvement of Tef [Eragrostis tef (Zucc.)] Trotter] in Central zone of Tigray,Ethiopia. Journal of Biology, Agriculture and Healthcare, (Vol.6), No.1, 2016

Ali M. A. Abouzar. Saeid B. Hashem A. 2011. Effect of different levels of nitrogen and plant spacing on yield, yield components and physiological indices in high-yield rice (number 843). American-Eurasian Journal Agricultural and Environment Science, 10(5):893 - 900.

Amare A. and Adane Legas - Determination of Seed Rate and Variety on the Growth and Yield of Teff in Eastern Amhara Region, Ethiopia

Awan,T. H., R. I. Ali, Z. Manzoor, M. Ahmad, M. Akhtar. 2011. Effect of different nitrogen levels and row spacing on the performance of newly evolved medium grain rice variety, KSK-133. Journal of Animal and Plant Sciences, 21(2):231 - 234

Bekele, HK., Verkuijl, H., Mwangi, W., Tanner, D. 2000. Adoption of

Improved Wheat Technologies in Adaba and Dodola Woredas of the Bale

Highlands, Ethiopia. Second National Maize and Wheat Workshop.12-16

November 2000; Addis Ababa. International Maize and Wheat

Improvement Center) and Ethiopian Agricultural Research Organization

(EARO). Addis Ababa, Ethiopia.

Cheng, A., Mayes, S., Dalle, G., Demissew, S. and Massawe, F. (2017). Diversifying crops for food and nutrition security-a case of teff. Biological Reviews, 92(1): 188-198, https://doi.org/10.1111/brv.12225

CIMMYIT (Centro International de Maiz Y Triggo. International Maize and Wheat Improvement Center). 1988. From Agronomic Data to Farmer Recommendations: An Economics Training Manual. Completely Revised Edition, Mexico, DF.79 pp.

CSA - Central Statistical Authority (2014). Report on area and production for major crops, Statistical Bulletin (1). Ethiopia.

CSA - Central Statistical Authority (2016). Report on area and production of crops: Central Statistical Agency. Statistical Bulletin, Volume I: 532, Addis Ababa.

Debebe, A. (2005) Performance of F4 progenies and Association amongyield and yield related traits in tef (Eragrostis tef (Zucc) Trotter). Alemaya University, Ethiopia.

Donald, L.S. 2004. Understanding and reducing lodging in cereals. Advances in Agronomy 84: 217-271.

Dutta, D., M.A.R. Sarker, M.A. Samad, S.K. Paul. 2002. Effect of row arrangement and Nitrogen level and the yield and yield components of transplant a man rice. Journal of Biological Sciences, 2(10):636 - 638 .

Ermias A, Akalu T, Alemayehu A, Melaku W and Tilahun T. 2007(eds). Proceedings of the 1st Annual Regional Conference on Completed Crop Research Activities, 14-17 August 2006. Amhara Regional Agricultural Research Institute. Bahir Dar, Ethiopia.

Firdisa B. (2016) - Determinants of Smallholder Farrmers' Participation Decision in Teff Production: Evidence from Horo and Jimma Geneti Woreda, Ethiopia.

Frietal, P., J. Dewis. 1970. Physical and Chemical Methods of Soil and Water Analysis. Bull. No_10. Food and Agriculture Organization of the United Nations, Rome, Italy.

Gorgy, N., 2010. Effect of transplanting spacing and nitrogen levels on growth, yield and nitrogen use efficiency of some promising rice varieties. Journal of Agricultural Research Kafer El-Shiekh University, 36(2):123146. 
Haftamu Gebretsadik, Mitiku Haile, Charles F. Yamoah. 2009. Tillage Frequency, Soil Compaction and NFertilizer Rate Effects on Yield of Tef [Eragrostis tef (Zucc.) Trotter] in Central Zone of Tigray, Northern Ethiopia Thesis presented to Mekelle University, Ethiopia.

Hasanuzzaman, M. K., Nahar, T.S. Roy, M.L. Rahman, M.Z. Hossain, J.U. Ahmed. 2009. Tiller Dynamics and Dry Matter Production of Transplanted Rice as Affected by Plant Spacing and Number of Seedling per Hill. Academic Journal of Plant Sciences, 2 (3): 162-168.

Havlin, John L.; J.D. Beaton; S.L. Tisdale; W.L. Nelson. 1999. Soil Fertility and Fertilizers: An Introduction to Nutrient Management. Sixth Edition, Prentice Hall, Inc. 86-195.

Hussain, M., Z. Mehmood, M. B. Khan, S. Farooq, D.J. Lee and M. Farooq. 2012. Narrow Row Spacing Ensures Higher Productivity of Low Tillering Wheat Cultivars. International Journal of Agriculture and Biology, $14: 413-418$

Islam, M. S., M. A. Hossain, M. A. H. Chowdhury, M. A. Hannan. 2008. Effect of nitrogen and transplanting date on yield and yield components of aromatic rice. Journal of Bangladesh Agricultural University, 6(2): 291296.

Ketema, S. (1997). Tef (Eragrostis tef) promoting the conservation and use of under-utilized and neglected crops. Biodiversity Institute, Addis Ababa, Ethiopa. pp. 24.

Ketema, S. (1997). Tef (Eragrostis tef) promoting the conservation and use of under-utilized and neglected crops. Biodiversity Institute, Addis Ababa, Ethiopa. pp. 24.

Mahato, P., S.K. Gunri, K. Chanda, M. Ghosh. 2007. Effect of varying levels of fertilizer and Spacing on medium duration rice (Oryza sativa L.) in Tarai Zone of West Bengal. Karnataka Journal of Agricultural Science, 20(2): 363-365.

Minten, B., Seneshaw, T., Ermias, E. and Tadesse, K. (2013). Ethiopia's Value Chains on the Move: The Case of Tef. Ethiopian Strategic Support Program, Working Paper 52. Addis Ababa, Ethiopia.

Olsen, S.R., C.V. Cole, F.S. Watanbe, L.A. Dean. 1954. Estimation of Available phosphorus in soils by extraction with sodium bicarbonate. USDA-ARS Circ. 939.

Rahman, M. A., A. J. M. S. Karim, M. A. Shaheed, M. A. Samad. 2000. A study on the effect of irrigation and nitrogen fertilization on uptake and efficiency of nitrogen in wheat. Bangladesh. J. Agril. Res. 25(4): 578583.

Roy, R.N., Finck, A., Blair, G.J., Tandon, H.L. 2006. Plant nutrition for food security: A guide for integrated nutrient management. FAO Fertilizer and Plant Nutrition Bulletin 16. Food and Agriculture Organization of the United Nations, Rome, Italy. Pp. 368.

Sahlemedhin Sertsu. 1999. Draft guideline for regional soil testing laboratories. NFIA, Addis Abeba, Ethiopia.

Sahlemedhin Sertus and Taye Bekele. 2000. Procedure for soil and plant analysis. Technical Bulletin No. 74. National Soil Research Center, Ethiopian Agricultural Organization, Addis Ababa, Ethiopia.

Sate S. and Tafese A. 2016 - Effects of Sowing Methods and Seed Rates on Yield Components and Yield of Tef in Soro Woreda, Hadya Zone, Southern Ethiopia.

Serrano, L., I. Filella, J. Penuelas. 2000. Remote Sensing of biomass and yield of winter wheat under different nitrogen supplies, Crop Science, 40: 723-731.

Sultana, M.R., M.M. Rahman, M. H. Rahman. 2012. Effect of row and hill spacing on the yield performance of boro rice (cv. BRRI dhan45) under aerobic system of cultivation. Journal of Bangladesh Agricultural University, 10(1): $39-42$.

Temesgen K. 2001. The effect of sowing date and nitrogen fertilizer on yield and yield traits of tef [Eragrostis tef (Zucc.) Trotter]. M.Sc. Thesis. Alemaya University of Agriculture, Ethiopia pp.: 30-36.

Tesfahun, W. (2018). Tef Yield Response to NPS Fertilizer and Methods of Sowing in East Shewa, Ethiopia. Journal of Agricultural Sciences, 13(2): 162-173.

Tesfay, T. and Gebresamuel, G. (2016). Agronomic and economic evaluations of compound fertilizer applications under different planting methods and seed rates of tef [Eragrostis tef (Zucc.) Trotter] in northern Ethiopia. Journal of Drylands, 6(1): 409-422.

Walkley A. and Black C.A. 1934. An examination of the Degtjareff method for determining organic matter and proposed modification of the chromic acid titration methods. Soils Science. 37:29-38.

Wubante N, Ahadu M. and Mulatu K, 2017 - Effect of Row Spacing on Yield and Yield Components of Teff [Eragrostis tef (Zucc.) Trotter] Varieties in Gonji Kolela District, North Western Ethiopia

Yoseftabar, S. 2013. Effects of nitrogen and phosphorus fertilizer on spikelet structure and yield in rice (Oryza sativa L.). International Journal of Agriculture and Crop Sciences, 5 (11): 1204-1208. 